\title{
Pathogenic threats and probiotic use in larviculture of the scallop, Pecten maximus
}

\author{
Aditya Kesarcodi-Watson ${ }^{1,2,{ }^{*}}$, Philippe Miner $^{1}$, Jean-Louis Nicolas ${ }^{1}$, Katia Asmani $^{1}$ and Rene Robert ${ }^{3}$
}

1 Laboratoire de Physiologie des Invertébrés, IFREMER Centre de Brest, Plouzané, France

2 Aquaculture and Biotechnology Department, Cawthron Institute, Nelson, New Zealand

3 Station Expérimentale d'Argenton, IFREMER Centre de Brest, Plouzané, France

*: Corresponding author : Aditya Kesarcodi-Watson, email address : aditya.kesarcodi-watson@cawthron.org.nz

\begin{abstract}
:
During a series of experiments, bacteriological elements in scallop larval rearing were investigated: larvae susceptibility to pathogens as a function of their age, and the use of probiotic bacteria during larviculture. Younger larvae (d5 PF) were highly more susceptible to pathogenic-challenge than their older siblings, which were challenged at an older age (d15 PF). A challenge with $10^{4} \mathrm{CFU} \mathrm{mL}^{-1}$ of $V$. pectenicida killed $100 \%$ of d5 PF larvae 7 days following challenge, yet killed only $9 \%$ of d15 PF larvae 9 days following challenge. Use of the probiotics Phaeobacter gallaeciensis, Alteromonas macleodii 0444 and Neptunomonas sp. 0536, provided for larger larvae, a high yield of competent larvae and, perhaps more importantly, protection against pathogen-challenge similar to levels achieved from antibiotic use. When challenged with $V$. pectenicida, d29 survivals were $20.3 \%, 85.1 \%$ and $75.0 \%$ respectively for control (no probiotic), antibiotic treated, and 'probiotic mix' administered larvae. Use of potential probiotic Pseudoalteromonas sp. D41 appeared to hinder scallop larvae. Future use of probiotics in scallop larval rearing would benefit from combined use of $P$. gallaeciensis, $A$. macleodii 0444 and Neptunomonas sp. 0536.
\end{abstract}

Keywords: scallop ; Pecten maximus ; Probiotics ; Alteromonas macleodii ; Neptunomonas ; Phaeobacter

\section{Introduction}

The worldwide market for scallops represents 2.4 million tonnes p.a. of which a very large proportion (66\%) derives from aquaculture (FAO Fisheries \& Aquaculture Information \& Statistics Service 2010). This large contribution by aquaculture mainly involves on-growing scallops from the wild, as opposed to the dredging of sea beds, which is how the capture fisheries operate. The main countries for scallop aquaculture are China ( $82 \%$ of total aquaculture) and Japan (16\%); while Chile, Peru, Canada, Sth. Korea, Russia, Brazil, Ireland, United Kingdom, Norway and Spain also have established industries. With these statistics in mind, it can be seen that there is benefit to be had in many countries from the hatchery production of scallop larvae. Such production would greatly assist the aquaculture-lopsided industry through means 
71 of a reliable product (avoiding seasonal fluctuations/spat collection inconsistencies)

72 and stock enhancement through selective breeding.

73

74

75

76

77

78

79

80

81

82

83

84

85

86

87

88

89

90

91

92

93

94

95

96

97

98

99

100

101

102

103

104

Larval production of the great scallop, Pecten maximus, does occur at present (Torkildsen \& Magnesen, 2004; Merino, Uribe, Soria \& von Brand, 2009; Andersen, Christophersen \& Magnesen, 2013) but much improvement is still needed. Inconsistent yields plague commercial production with many potential implicating factors; feed quality, broodstock conditioning, water quality/consistency (Andersen, Christophersen \& Magnesen, 2011). Current commercial production mostly employs static batch culture rather than continuous flow and the use of antibiotics remains often essential for successful larviculture. However, like other forms of aquaculture, the use of antibiotics needs to be reviewed and alternatives sought (Kesarcodi-Watson, Kaspar, Lategan \& Gibson, 2008). Use of probiotic bacteria has been demonstrated to be effective in bivalve larviculture (Riquelme, Jorquera, Rojas, Avendaño \& Reyes, 2001; Kesarcodi-Watson, Kaspar, Lategan \& Gibson, 2010). Recently, it was shown that four species of probiotics were able to protect $P$. maximus larvae against pathogen-challenge by Vibrio spp., under the conditions of a multi-well plate bioassay (Kesarcodi-Watson, Miner, Nicolas \& Robert, 2012).

When compared with the larvae of other bivalves such as oysters and mussels, $P$. maximus larvae have proven more difficult to culture successfully (Robert \& Gérard, 1999; Helm, Bourne \& Lovatelli, 2004); they appear to be more sensitive to biotic (bacteria) and abiotic factors (tank design/culture technique). The highly variable production output which occurs at present offers risk to the farmer and needs to be improved. To do this, all aspects of scallop larval rearing warrant investigation to find possible areas that allow less variable and improved output. In the present study, bacteriological aspects concerning scallop larval rearing were investigated. Firstly, the effect of the age of scallop larvae upon pathogen susceptibility was investigated.

Secondly, the effect of four probiotics was determined during the full larval cycle of scallop. The probiotics were tested both individually and in a multi-strain mix containing all. Each probiotic treatment was tested during routine unchallenged rearing and also against a pathogen-challenge by $V$. pectenicida.

\section{Materials and methods}


Scallop larvae were obtained from the private hatchery of "Le Tinduff" (Brittany,

109 France) at $\mathrm{d} 2$ post-fertilization (PF) when fertilized eggs had hatched to provide D-

110 larvae. Larvae were transported to IFREMER Brest (Brittany, France), for

111 experiments. Between d2 PF and d6 PF, larvae were reared collectively in a 1501

112 conical tank with gentle aeration $\left(31 \mathrm{~h}^{-1}\right)$ at a concentration of approximately 13

113 larvae $\mathrm{ml}^{-1}$. Water temperature was maintained at $19^{\circ} \mathrm{C}$, filtered to $1 \mu \mathrm{m}$, and U.V.

114 sterilized. Water was changed every two days. At each water change, larvae were fed

115 a 1:1:1 mix of Pavlova lutheri (P), Tisochrysis lutea (formerly Isochrysis aff.

116 galbana: T-Iso) (T) and Skeletonema marinoi (S), each at 20 cells $\mu 1^{-1}$.

118 Larvae were treated with antibiotics (chloramphenicol 8ppm); one treatment for the

119 "age as a factor of pathogen susceptibility" study at d2 PF, and two treatments for the

120 probiotic trial, at $\mathrm{d} 2$ and $\mathrm{d} 4 \mathrm{PF}$. The treatments were timed to allow three days to pass

121 before experimental pathogen-challenge. Although now banned for commercial

122 application, chloramphenicol was chosen for the present study as it has been used

123 historically on an experimental basis in P. maximus larviculture with greater success

124 than other antibiotics (Le Pennec, Prieur \& Chardi, 1973; Robert, Miner \& Nicolas,

125 1996). Antibiotic treatment, at least once, at the beginning of $P$. maximus larval

126 rearing is currently imperative. Trials rearing scallop larvae without this initial

127 treatment were not successful, even when probiotics were used (unpublished data);

128 this is believed to be a result of the Vibrio spp., which can be eliminated by this initial

129 antibiotic treatment.

130

\subsection{Bacteriology}

132

133 For trials with probiotic bacteria, four strains of potential probiotics were used:

134 Alteromonas macleodii 0444, Neptunomonas sp. 0536 (Kesarcodi-Watson et al.,

135 2010), Phaeobacter gallaeciensis (Ruiz-Ponte, Cilia, Lambert \& Nicolas, 1998),

136 Pseudoalteromonas sp. D41 (Kesarcodi-Watson et al., 2012). For trials involving a

137 pathogen-challenge, $V$. pectenicida or $V$. splendidus were used. Strains were revived

138 from $-80{ }^{\circ} \mathrm{C}$ stores in Marine Broth (Difco) at appropriate temperatures: A. macleodii 
0444, Pseudoalteromonas sp. D41 at $37^{\circ} \mathrm{C}$; Neptunomonas sp. 0536 at $30{ }^{\circ} \mathrm{C} ; \mathrm{P}$. gallaeciensis at $25^{\circ} \mathrm{C} ; \mathrm{V}$. pectenicida, $V$. splendidus at $20^{\circ} \mathrm{C}$. Each strain was then sub-cultured three times on Marine Agar (Difco) to ensure purity before use in trials. Prior to use in experiments, bacteria were cultured in $10 \mathrm{ml}$ Marine Broth (Difco) for $24 \mathrm{~h}$ at the appropriate temperatures. After culture, cells were centrifuged $(2500 \mathrm{~g}, 8$ min, $20^{\circ} \mathrm{C}$ ) and washed twice with sterile seawater, ready for use in experiments. Washed cells were enumerated following serial dilution and plating onto Marine Agar, allowing the concentrations used for each experiment to be verified.

\subsection{Age as a factor in the pathogen susceptibility of scallop larvae}

It was investigated whether the age of larvae influenced their susceptibility to pathogen-challenge. Larvae originating from the same cohort of $P$. maximus were challenged at two different ages; d5 PF and d15 PF. During the first pathogenchallenge, the larvae were challenged with two pathogens separately, $V$. pectenicida and $V$. splendidus, at three concentrations: $10^{4}, 10^{5}$ and $10^{6}$ colony forming units $\mathrm{ml}^{-1}$ $\left(\mathrm{CFU} \mathrm{ml} \mathrm{l}^{-1}\right)$. The pathogens were added $24 \mathrm{~h}$ after water change and $24 \mathrm{~h}$ before the next change. Larval survival was measured for nine days following pathogenchallenge and then the larvae were discarded. Those larvae used in the d15 PF trial originated from the same cohort but had no previous exposure to the pathogen and had been reared in a 1501 conical tank with gentle aeration and water changes every two days. The second pathogen-challenge repeated the challenge with just $V$. pectenicida (because $V$. splendidus had minimal effect upon d5 PF larvae). The second challenge also employed three concentrations of $V$. pectenicida $\left(10^{4}, 10^{5}, 10^{6}\right.$ $\mathrm{CFU} \mathrm{ml^{-1 }}$ ). For both trials, flat-bottom beakers (2 1) filled to 1.51 with $1 \mu \mathrm{m}$ filtered, U.V. sterilized seawater $\left(19^{\circ} \mathrm{C}\right)$ were used. Larvae were placed at a concentration of 10 larvae $\mathrm{ml}^{-1}$. Water changes of all tanks occurred every two days and larvae were fed at water changes as described previously. A control treatment contained nonchallenged larvae. All treatments were conducted in triplicate.

\subsection{Probiotic trials during scallop larval rearing}

\subsubsection{Probiotic trials}


173 Larvae were obtained as described in section 2.1. At d6 PF, larvae were placed into 21

174 flat-bottom beakers filled with 1.51 of $1 \mu \mathrm{m}$ filtered, U.V. sterilized seawater $\left(19^{\circ} \mathrm{C}\right)$.

175 Larvae were placed into each beaker at 10 larvae $\mathrm{ml}^{-1}$. Water was changed every two

176 or three days depending on practicality. Probiotic addition was provided after each

177 water change; first commencing on d6 PF and ceasing on d24 PF. Treatments

178 comprised the probiotics A. macleodii 0444, Neptunomonas sp. 0536, P. gallaeciensis

179 and Pseudoalteromonas sp. D41, given individually or in a mix (giving $1 / 4$ of the

180 quantity used by each inoculum in the individual treatments into one treatment).

181 Another treatment provided antibiotic administration (chloramphenicol 8ppm) at each

182 water change, without probiotics, allowing comparison to be made between probiotic

183 and antibiotic efficacy. A control treatment contained larvae without addition of

184 probiotic or antibiotic at water changes. All experimental conditions were carried out

185 in triplicate.

186

187 Following preparation for their use in experiments ( $24 \mathrm{~h})$, each strain was

188 administered at the highest possible concentration (Table 1), determined by the end-

189 concentration of each probiotic culture. Furthermore, because the growth rates of

190 probiotics differed (resulting in a range of end-concentrations), the final "in-tank"

191 concentration of each probiotic ranged between $10^{4}-10^{5} \mathrm{CFU} \mathrm{ml}{ }^{-1}$ on the

192 administration days. These concentrations were the same as those tested previously

193 which demonstrated a positive probiotic effect upon scallop larvae (Kesarcodi-Watson

194 et al., 2012).

195

196 Throughout the trial, larval survival was measured via microscope analysis at each

197 water change. Additionally, larval shell sizes were measured on d16, 24, 27 and 29

198 using a Leica DMIL microscope equipped with a CCD camera and image analysis by

199 Image SXM software. The yield of competent larvae, i.e. the proportion of larvae to

200 achieve metamorphosis capability (as determined by appearance of a "double-bar" on

201 the velum in the late stages of larval development), was recorded also at d21, 24, 27

202 and 29.

203

204 TABLE 1.

205 
208 In a concurrent trial, larvae administered probiotics in the same manner as in section

209 2.4.1., were challenged with $10^{4} \mathrm{CFU} \mathrm{m}{ }^{-1} \mathrm{~V}$. pectenicida on $\mathrm{d} 7 \mathrm{PF}$ ( $24 \mathrm{~h}$ after the first

210 probiotic administration and $24 \mathrm{~h}$ before the next water change). Probiotic supply was

211 continued with these larvae until d24 PF. Larval survival and the yield of competent

212 larvae were measured as in section 2.4.1. All treatments were applied in triplicate.

\subsection{Data analysis}

Percent survival figures were arc sin square root transformed to approximate normality. Treatment differences were compared using ANOVA $(p=0.05)$. Post hoc comparisons between survivals were compared using Tukey's test. Larvae size data were compared using nonparametric Kruskal-Wallis analysis. STATISTICA (StatSoft, Inc.), version 7.1 was used for data analysis.

\section{Results}

\subsection{Age as a factor of scallop larvae pathogen susceptibility}

Young larvae (d5 PF) from the tested cohort were not highly susceptible to $V$. splendidus with only high levels of $V$. splendidus $\left(10^{6} \mathrm{CFU} \mathrm{ml}^{-1}\right)$ resulting in a small mortality increase above those in the control treatment (Table 2). However, challenge of d5 PF larvae with $V$. pectenicida resulted in large mortalities at all concentrations

230 (Table 2). Furthermore, at the smallest pathogen inoculum tested $\left(10^{4} \mathrm{CFU} \mathrm{ml}^{-1}\right)$ all

231 larvae had died seven days following challenge with $V$. pectenicida. When d15 larvae

232 were challenged, there was a far greater resistance to $V$. pectenicida (Table 2); $10^{4}$

$233 \mathrm{CFU} \mathrm{m}{ }^{-1}$ of the pathogen resulted in just $9 \%$ mortality nine days following challenge.

234 Furthermore, pathogen-challenge with a higher level of the bacterium $\left(10^{5} \mathrm{CFU} \mathrm{ml}{ }^{-1}\right)$

235 resulted in only $24 \%$ mortality nine days post-challenge in d 15 larvae, despite the

236 same level of pathogen obliterating d5 PF larvae just three days following challenge.

\subsection{Probiotic trials}


242 High larval survivals occurred in all treatments during the full larval period (Table 3).

243 There were occasional statistical differences, yet in terms of absolute percentage

244 larval survivals, these differences were very minor and were not present by the end of

245 the trial (d29). Differences were, however, seen between treatments in terms of larval

246 size (Table 3) and the yield of competent larvae (Fig. 1A). The largest larvae were

247 observed in the control and also those administered A. macleodii 0444 or $P$.

248 gallaeciensis (Table 3). Those provided Pseudoalteromonas sp. D41 and the mix of

249 all probiotics grew the slowest. In terms of the competent larvae yields,

250 Pseudoalteromonas sp. D41 and the antibiotic treatment performed worse than the

251 other treatments; the other treatments being statistically no different to each other (Fig.

$2521 \mathrm{~A})$.

253

254 TABLE 3

255 FIGURE 1

256

257

\subsection{Pathogen-challenge trials}

259 When challenged with $V$. pectenicida, larvae administered chloramphenicol had the

260 highest absolute survivals; however, protection against the challenge was statistically

261 no different to the use of antibiotics when either $P$. gallaeciensis or the probiotic-mix

262 were administered (Table 4). These three treatments provided the best protection

263 against pathogen-challenge; yet, administration of $A$. macleodii 0444, Neptunomonas

264 sp. 0536 and Pseudoalteromonas sp. D41 also provided protection against the

265 challenge when compared with the untreated pathogen-control larvae (Table 4). In

266 terms of competent larvae yields reached following pathogen-challenge, $P$.

267 gallaeciensis and the probiotic-mix performed the best; whereas, the pathogen-control

268 and Pseudoalteromonas sp. D41 did the worst (Fig. 1B).

TABLE 4

271

272

\section{Discussion}

273 
274 To date, attempts at $P$. maximus larviculture have shown the animals to be more

275 sensitive than other commercially reared bivalve mollusks. They have displayed much

276 more vulnerability to bacterial problems, often reliant on antibiotic use (Robert el al.,

277 1996; Merino et al., 2009). The data provided in this study show that factors

278 including: larval age, and the use of probiotics can have a large influence upon the

279 success of a batch of scallop larvae.

280

281 Observation that older larvae had greater resistance to pathogen attack is important.

282 Whilst this occurrence might seem somewhat obvious, we are not aware of other

283 studies which have investigated this aspect. Mollusk larviculture is a vulnerable time

284 for the animals being cultured; however, we can now say, at least with P. maximus

285 larvae, that larvae which survive the first two weeks of culture are less likely to

286 succumb to pathogenic bacteria. A likely reason why older larvae withstand pathogen-

287 challenge better than younger larvae is due to the increased lipid levels that are found

288 in older larvae (Marty, Delaunay, Moal \& Samain, 1992; Soudant, Marty, Moal,

289 Masski \& Samain, 1998). These authors observed significant increases in the total

290 lipids (ng larva ${ }^{-1}$ ) of P. maximus larvae, reaching as high as a 10-fold increase

291 between d2 and d23 PF (Soudant et al., 1998). As well as nutrition, lipids can have

292 structural, functional and immune properties. Pernet, Bricelj \& Parrish (2005) found

293 an increase in arachidonic acid, 20:4(n-6), in larval sea scallop, Plactopecten

294 magellanicus, and discussed how this PUFA had been implicated in mediation of

295 cellular responses to bacterial infections in insects. Another possible reason for

296 increased pathogen resistance in older larvae might be due to the natural resident

297 bacteria which colonize the larvae. A more developed microflora population might

298 offer natural bacterial defenses against pathogens. Indeed, study of other aquatic

299 animals have shown a shift in dominant bacterial groups during the larval cycle

300 (Bergh, Naas \& Harboe, 1994), and perhaps it is the groups which colonize at the later

301 stages which offer enhanced protection against the pathogens. In scallop larvae,

302 bacterial effects have not been studied as highly as lipids; however in the present

303 study we have shown that bacteria have the potential to limit pathogenic effects. It is

304 likely that a natural bacterial population develops in older larvae strengthening them

305 against pathogenic challenges and this is an area which deserves investigation. 
307 Probiotic use during this study provided advantages to: larval size, yields of

308 competent larvae, and also in protecting larvae against pathogen-challenge. None of

309 the probiotics tested in this study affected the survival of scallop larvae during routine,

310 unchallenged rearing. During routine rearing, the probiotics $P$. gallaeciensis and $A$.

311 macleodii 0444 showed merit by producing both the largest larvae and highest yield

312 of competent larvae. Interestingly, despite the larvae inoculated with Neptunomonas

313 sp. 0536 not being the largest larvae, they achieved the highest absolute yield of

314 competent larvae. The reason for this is unclear, but it is certainly a useful trait. For

315 these reasons, a probiotic mix is probably a good option for future probiotic use. This

316 mix should exclude Pseudoalteromonas sp. D41 which displayed the slowest growth

317 and lowest yield of competent larvae, both being worse than the control larvae. It

318 should be mentioned that a strain of Pseudoalteromonas spp. has been described as an

319 opportunistic pathogen of P. maximus larvae (Sandaa, Brunvold, Magnesen \& Bergh,

320 2008). In the present study, when scallop larvae were challenged with $V$. pectenicida,

321 the probiotic-mix provided high larval survivals which, along with individual

322 administration of $P$. gallaeciensis, protected larvae to a level no different to that

323 observed when antibiotic was used. This benefit was also witnessed in the yields of

324 competent larvae, with the probiotic-mix producing the best performing larvae

325 following pathogen-challenge. It appears that during routine rearing, and also as a

326 protective measure against pathogen attack, administration of a mixture of $A$.

327 macleodii 0444, P. gallaeciensis and Neptunomonas sp. 0536 provides desirable

328 attributes to P. maximus larval rearing. Data from the probiotic-mix were potentially

329 undervalued due the mix incorporating Pseudoalteromonas sp. D41, which was

330 negative to the larvae, and the benefits provided from a revised probiotic-mix could

331 be investigated in the future.

333 Previous studies also investigated probiotics in scallop larviculture (Riquelme,

334 Hayashida, Araya, Uchida, Satomi \& Ishida, 1996; Riquelme, Araya, Vergara, Rojas,

335 Guaita \& Candia, 1997; Avendaño \& Riquelme, 1999; Ruiz-Ponte, Samain, Sánchez

336 \& Nicolas, 1999; Riquelme, Araya \& Escribano, 2000; Riquelme et al., 2001). All

337 studies except that of Ruiz-Ponte et al. (1999) investigated the Chilean scallop, $A$.

338 purpuratus. Like the present study, Riquelme et al. (1996) found a member of the

339 genus Alteromonas (A. haloplanktis) to be beneficial against pathogen-challenge.

340 Another study by Riquelme et al. (2001) incorporated probiotics into commercial- 
341 scale hatchery production using the bacterial strains C33, strain 11, and Bacillus sp.

342 (strain B2). The study showed that the probiotics allowed completion of the larval

343 cycle without the need to use antibiotics. Similar to the current study, Ruiz-Ponte et al.

344 (1999) tested P. gallaeciensis upon P. maximus larvae; however, they found that

345 neither pathogen-challenged nor unchallenged larvae were protected by live bacterial

346 cells of $P$. gallaeciensis. Our findings are in conflict with those of Ruiz-Ponte et al.

347 (1999); herein, P. gallaeciensis was the best performing probiotic, providing

348 protection against pathogen attack no different to when antibiotic was used. Ruiz-

349 Ponte et al. proposed that perhaps $P$. gallaeciensis produced substances toxic to the

350 larvae, which were more pronounced at higher levels of $P$. gallaeciensis, or that

351 perhaps the organic matter introduced with higher levels of $P$. gallaeciensis aided in

352 pathogen proliferation. If true, these could potentially explain the differences in their

353 results and those in the current study because they administered P. gallaeciensis at $10^{6}$

$354 \mathrm{CFU} \mathrm{ml}{ }^{-1}$ whereas $10^{4}-10^{5} \mathrm{CFU} \mathrm{ml}^{-1}$ was used in the current study. Additionally, the

355 ambient bacterial community would most certainly have been different between the

356 present study and that of Ruiz-Ponte et al. (1999); and this also might have influenced

357 the effect of probiotic addition.

359 One conspicuous aspect of current $P$. maximus larviculture is the use of antibiotics in

360 the early stages. Trials conducted with/without two doses of chloramphenicol (at d3

361 and $\mathrm{d} 4 \mathrm{PF}$ ), using the same batch of larvae, showed that those not provided the

362 antibiotic underwent large mortality whilst those provided the antibiotic did not (A.

363 Kesarcodi-Watson, unpublished data). This is a regular occurrence with $P$. maximus

364 larvae (Robert et al., 1996; Torkildsen, Lambert, Nylund, Magnesen \& Bergh, 2005)

365 and it appears the Vibrio spp. which are present in these early stages (detected by

366 culture on TCBS agar plates) need to be eliminated by antibiotics to allow scallop

367 larvae to proceed successfully. Furthermore, because best efforts are made to sterilize

368 larval rearing waters ( $1 \mu \mathrm{m}$ filtered, U.V. sterilized) yet Vibrio spp. still occur in early

369 larval rearing waters, it appears that these bacteria enter $P$. maximus larval rearing

370 systems via vertical transmission from the broodstock (Holbach, $\mathrm{PhD}$ in prep), also

371 put forward for Chilean scallop, Argopecten purpuratus (Riquelme, Hayashida,

372 Toranzo, Vilches \& Chavez, 1995). 
374 Recent work in Norway developed low-exchange continuous-flow techniques for $P$.

375 maximus larval rearing which allowed successful larval rearing in the absence of

376 antibiotics (Andersen, Burnell \& Bergh, 2000; Torkildsen \& Magnesen, 2004;

377 Magnesen et al., 2006; Andersen et al., 2013). During this work, a very low water

378 turn-over (approximately one tank exchange per day) and low density of larvae (3.0-

3795.2 larvae $\mathrm{ml}^{-1}$ starting density, with a final density at settlement of 1.0 larvae $\mathrm{ml}^{-1}$ )

380 were used (Magnesen et al., 2006, Andersen et al., 2013). The work in Norway lays a

381 good foundation to antibiotic-free scallop larviculture (in an industry with increasing

382 restrictions on antibiotic use), but with such low water exchange it currently remains a

383 slightly more intensive version of a batch-culture system; improvements in stocking

384 density and water-flow would be desirable to provide efficient larval rearing. To our

385 knowledge, commercial rearing of scallop larvae by flow-through techniques is

386 currently practiced only in Norway.

388 Continued research is needed into scallop larval rearing to facilitate regular and

389 untroubled production. The results from this study provide useful information for

390 direct application in scallop larviculture and also highlight further research avenues.

\section{Acknowledgements}

393 We wish to thank staff at "Le Tinduff" hatchery for providing the larvae. This work

394 was supported by both the New Zealand government's Ministry of Business,

395 Innovation, and Employment; contract CAWX0802 'Adding Value to New Zealand's

396 Cultured Shellfish Industry: Maximising Profit, Minimising Risk' and an IFREMER

397 Post-Doctoral Fellowship.

\section{References}

400 Andersen, S., Burnell, G., Bergh, Ø., 2000. Flow-through systems for culturing great $401 \quad$ scallop larvae. Aquacult. Int. 8, 249-257.

402 Andersen, S., Christophersen, G., Magnesen, T., 2011. Spat production of the great 403 scallop (Pecten maximus): a roller coaster. Can. J. Zool. 89, 579-598.

404 Andersen, S., Christophersen, G., Magnesen, T., 2013. Implications of larval diet 405 concentration on post-larval yield in a production scale flow-through system for 406 scallops (Pecten maximus Lamarck) in Norway. Aquacult. Int. 21, 435-452. 
Avendaño, R.E., Riquelme, C.E., 1999. Establishment of mixed probiotics and microalgae as food for bivalve larvae. Aquac. Res. 30, 893-900.

Bergh, Ø., Naas, K.E., Harboe, T., 1994. Shift in intestinal microflora of Atlantic halibut (Hippoglossus hippoglossus) larvae during first feeding. Can. J. Fish. Aquat. Sci. 51, 1899-1903.

FAO Fisheries and Aquaculture Information and Statistics Service. 2010. Aquaculture production 1950-2008. FISHSTAT Plus - Universal software for fishery statistical time series [online or CD-ROM]. Food and Agriculture Organization of the United Nations. Available at: http://www.fao.org/fishery/statistics/software/fishstat/en

Helm, M.M., Bourne, N., Lovatelli, A., 2004. Hatchery culture of bivalves. A practical manual. In: Lovatelli, A. (Ed.), FAO Fisheries Technical Paper 471. Food and Agriculture Organization of the United, Nations Publishing, Rome, Italy. $177 \mathrm{pp}$.

Kesarcodi-Watson, A., Kaspar, H., Lategan, M.-J., Gibson, L., 2008. Probiotics in aquaculture: the need, principles and mechanisms of action and screening processes. Aquaculture 272, 1-14.

Kesarcodi-Watson, A., Kaspar, H., Lategan, M.-J., Gibson, L., 2010. Alteromonas macleodii 0444 and Neptunomonas sp. 0536, two novel probiotics for hatcheryreared Greenshell ${ }^{\mathrm{TM}}$ mussel larvae, Perna canaliculus. Aquaculture 309, 49-55.

Kesarcodi-Watson, A., Miner, P., Nicolas, J.-L., Robert, R., 2012. Protective effect of four potential probiotics against pathogen-challenge of the larvae of three bivalves: Pacific oyster (Crassostrea gigas), flat oyster (Ostrea edulis) and scallop (Pecten maximus). Aquaculture 344-349, 29-34.

Le Pennec, M., Prieur, D., Chardi, P., 1973. Développement larvaire de Mytilus edulis (L.) en presence d'antibiotiques. $2^{\text {éme }}$ partie: action sur la croissance de quatre antibiotiques: Auréomycine, Erythromycine, Chloramphenicol et Sulfamérazine. Revue Internationale d'Oceanographie Medicale 30, 115-137.

Magnesen, T., Bergh, Ø., Christophersen, G., 2006. Yields of great scallop, Pecten maximus, larvae in a commercial flow-through rearing system in Norway. Aquacult. Int. 14, 377-394.

Magnesen, T., Jacobsen, A., 2012. Effect of water recirculation on seawater quality and production of scallop (Pecten maximus) larvae. Aquacult. Eng. 47, 1-6.

Marty, Y., Delaunay, F., Moal, J. Samain, J.F., 1992. Changes in the fatty acid composition of Pecten maximus (L.) during larval development. J. Exp. Mar. Biol. Ecol. 163, 221-234.

Merino, G., Uribe, E., Soria, G., von Brand, E., 2009. A comparison of larval production of the northern scallop, Argopecten purpuratus, in closed and recirculating culture systems. Aquacult. Eng. 40, 95-103. 
Pernet, F., Bricelj, V.M., Parrish, C.C., 2005. Effects of varying dietary levels of $\omega 6$ polyunsaturated fatty acids during the early ontogeny of the sea scallop, Placopecten magellanicus. J. Exp. Mar. Biol. Ecol. 327, 115-133.

Ragg, N.L.C., King, N., Watts, E., Morrish, J., 2010. Optimising the delivery of the key diatom Chaetoceros calcitrans to intensively cultured Greenshell ${ }^{\mathrm{TM}}$ mussel larvae, Perna canaliculus. Aquaculture 306, 270-280.

Riquelme, C., Hayashida, G., Toranzo, A.E., Vilches, J., Chavez, P.,1995. Pathogenicity studies on a Vibrio anguillarum-related (VAR) strain causing and epizootic in Argopecten purpuratus larvae cultured in Chile. Dis. Aquat. Organ. 22, 135-141.

Riquelme, C., Hayashida, G., Araya, R., Uchida, A., Satomi, M., Ishida, Y., 1996. Isolation of a native bacterial strain from the scallop Argopecten purpuratus with inhibitory effects against pathogenic vibrios. J. Shellfish Res. 15(2), 369374.

Riquelme, C., Araya, R., Vergara, N., Rojas, A., Guaita, M., Candia, M., 1997. Potential probiotic strains in the culture of the Chilean scallop Argopecten purpuratus (Lamarck, 1819). Aquaculture 154, 17-26.

Riquelme, C., Araya, R., Escribano, R., 2000. Selective incorporation of bacteria by Argopecten purpuratus larvae: implications for the use of probiotics in culturing systems of the Chilean scallop. Aquaculture 181, 25-36.

Riquelme, C.E., Jorquera, M.A., Rojas, A.I., Avendaño, R.E., Reyes, N., 2001. Addition of inhibitor-producing bacteria to mass cultures of Argopecten purpuratus larvae (Lamarck, 1819). Aquaculture 192, 111-119.

Robert, R., Gérard, A., 1999. Bivalve hatchery techniques: current situation for the oyster Crassostrea gigas and the scallop Pecten maximus. Aquat. Living Resour., 12 (2), 121-130.

Robert, R., Miner, P., Nicolas, J.L., 1996. Mortality control of scallop larvae in the hatchery. Aquacult. Int. 4, 305-313.

Robert, R., Nicolas, L., Moisan, C., Barbier, G. 1999. Caractérisation morphologique et biochimique de la metamorphose de la coquille St Jacques Pecten maximus (Lamarck). C.R. Acad. Sci. Paris 322, 847-853.

Ruiz-Ponte, C., Cilia, V., Lambert, C., Nicolas, J.L., 1998. Roseobacter gallaeciensis sp. nov., a new marine bacterium isolated from rearings and collectors of the scallop Pecten maximus. Int. J. Syst. Bacteriol. 48, 537-542.

Ruiz-Ponte, C., Samain, J.F., Sánchez, J.L., Nicolas, J.L., 1999. The benefit of a Roseobacter species on the survival of scallop larvae. Mar. Biotechnol. 1, 52-59.

Sandaa, R.-A., Brunvold, L., Magnesen, T., Bergh, Ø., 2008. Monitoring the opportunistic bacteria Pseudoalteromonas sp. LT-13 in a great scallop, Pecten maximus hatchery. Aquaculture 276, 14-21. 
485

486

487

488

489

490

491

492

493

494

495
Soria, G., Merino, G., von Brand, E., Uribe, E., 2007. Culturing northern Chilean scallop Argopecten purpuratus larvae in closed and recirculating aquaculture systems. J. Shellfish Res. 26, 1347-1348.

Soudant, P., Marty, Y., Moal, J., Masski, H., Samain, J.F., 1998. Fatty acid composition of polar lipid classes during larval development of scallop Pecten maximus (L.). Comp. Biochem. Phys. A 121, 279-288.

Torkildsen, L., Lambert, C., Nylund, A., Magnesen, T., Bergh, Ø., 2005. Bacteria associated with early life stages of the great scallop, Pecten maximus: impact on larval survival. Aquacult. Int. 13, 575-592.

Torkildsen, L., Magnesen, T., 2004. Hatchery production of scallop larvae (Pecten maximus)- survival in different rearing systems. Aquacult. Int. 12, 489-507. 
Table 1. Probiotic concentrations in each treatment throughout scallop larval rearing. Note: $d=d a y, P F=P o s t-$ fertilization.

\begin{tabular}{|c|c|c|c|c|c|c|c|c|c|}
\hline \multirow[t]{2}{*}{ Treatment } & \multicolumn{9}{|c|}{ "in-tank" probiotic concentration following water changes } \\
\hline & d6 PF & d8 PF & $\mathrm{d} 10 \mathrm{PF}$ & $\mathrm{d} 12 \mathrm{PF}$ & d14 PF & d16 PF & d19 PF & $\mathrm{d} 21 \mathrm{PF}$ & $\mathrm{d} 24 \mathrm{PF}$ \\
\hline A. macleodii 0444 & $2.2 \times 10^{5}$ & $1.8 \times 10^{5}$ & $2.6 \times 10^{5}$ & $1.9 \times 10^{5}$ & $3.0 \times 10^{5}$ & $2.9 \times 10^{5}$ & $1.7 \times 10^{5}$ & $1.2 \times 10^{5}$ & $2.7 \times 10^{5}$ \\
\hline Neptunomonas sp. 0536 & $5.4 \times 10^{4}$ & $8.6 \times 10^{4}$ & $3.5 \times 10^{4}$ & $3.0 \times 10^{4}$ & $2.5 \times 10^{4}$ & $2.8 \times 10^{4}$ & $9.2 \times 10^{4}$ & $2.0 \times 10^{4}$ & $6.4 \times 10^{4}$ \\
\hline P. gallaeciensis & $1.3 \times 10^{5}$ & $1.8 \times 10^{5}$ & $7.0 \times 10^{4}$ & $7.3 \times 10^{4}$ & $7.0 \times 10^{4}$ & $5.0 \times 10^{4}$ & $6.5 \times 10^{4}$ & $7.3 \times 10^{4}$ & $6.0 \times 10^{4}$ \\
\hline Pseudoalteromonas sp. D41 & $4.5 \times 10^{4}$ & $1.9 \times 10^{4}$ & $1.9 \times 10^{4}$ & $1.7 \times 10^{4}$ & $1.7 \times 10^{4}$ & $2.9 \times 10^{4}$ & $8.4 \times 10^{4}$ & $2.3 \times 10^{8}$ & $6.5 \times 10^{4}$ \\
\hline Probiotic mix & $1 / 4$ of all & $1 / 4$ of all & $1 / 4$ of all & $1 / 4$ of all & $1 / 4$ of all & $1 / 4$ of all & $1 / 4$ of all & $1 / 4$ of all & $1 / 4$ of all \\
\hline
\end{tabular}


Table 2. Scallop larvae survival ( $\% \pm$ S.E.) after two separate pathogen-challenges with a range of concentrations. During the first challenge, $V$. pectenicida or $V$. splendidus was used. During the second challenge only $V$. pectenicida was used. Each challenge used the same cohort of larvae, although different ages of the larvae (i.e. $\mathrm{d} 5$ or $\mathrm{d} 15$ ). Values in a column with an asterix $(*)$ are statistically different to the unchallenged control $(\mathrm{p}<0.05)$.

\begin{tabular}{|c|c|c|c|c|c|c|c|c|c|}
\hline \multirow[b]{2}{*}{ Treatment } & \multicolumn{5}{|c|}{ First pathogen-challenge (challenged on d5) } & \multicolumn{4}{|c|}{ Second pathogen-challenge (challenged on d15) } \\
\hline & $\begin{array}{l}1 \text { day post- } \\
\text { challenge }\end{array}$ & $\begin{array}{l}3 \text { days post- } \\
\text { challenge }\end{array}$ & $\begin{array}{l}5 \text { days post- } \\
\text { challenge }\end{array}$ & $\begin{array}{l}7 \text { days post- } \\
\text { challenge }\end{array}$ & $\begin{array}{l}9 \text { days post- } \\
\text { challenge }\end{array}$ & $\begin{array}{l}1 \text { day post- } \\
\text { challenge }\end{array}$ & $\begin{array}{l}4 \text { days post- } \\
\text { challenge }\end{array}$ & $\begin{array}{l}6 \text { days post- } \\
\text { challenge }\end{array}$ & $\begin{array}{l}9 \text { days post- } \\
\text { challenge }\end{array}$ \\
\hline $\begin{array}{l}\text { Unchallenged } \\
\text { control }\end{array}$ & $100.0 \pm 0.0$ & $100.0 \pm 0.0$ & $98.3 \pm 0.6$ & $97.9 \pm 0.6$ & $97.1 \pm 1.4$ & $99.7 \pm 0.3$ & $99.3 \pm 0.7$ & $95.1 \pm 1.9$ & $99.2 \pm 0.6$ \\
\hline$V \cdot$ pectenicida $10^{6}$ & $28.9 \pm 4.1 *$ & $0.0 \pm 0.0 *$ & Discontinued & Discontinued & & $96.1 \pm 0.9 *$ & $41.2 \pm 2.8 *$ & $33.4 \pm 2.1 *$ & $21.8 \pm 2.4 *$ \\
\hline V. pectenicida $10^{5}$ & $98.2 \pm 0.6$ & $1.6 \pm 1.3 *$ & Discontinued & Discontinued & & $97.7 \pm 0.7$ & $86.6 \pm 3.5 *$ & $85.2 \pm 1.6 *$ & $75.7 \pm 1.4 *$ \\
\hline V. pectenicida $10^{4}$ & $98.9 \pm 0.5$ & $60.7 \pm 9.8 *$ & $21.5 \pm 4.8 *$ & Discontinued & & $98.9 \pm 0.5$ & $95.5 \pm 1.1$ & $94.6 \pm 1.2$ & $91.0 \pm 1.5 *$ \\
\hline V. splendidus $10^{6}$ & $92.1 \pm 1.7 *$ & $87.4 \pm 1.6 *$ & $79.9 \pm 2.5 *$ & $81.0 \pm 1.9^{*}$ & $75.5 \pm 4.0 *$ & & & & \\
\hline V. splendidus $10^{5}$ & $99.7 \pm 0.3$ & $98.5 \pm 0.9$ & $97.6 \pm 1.6$ & $97.5 \pm 0.9$ & $95.8 \pm 1.1$ & & & & \\
\hline V. splendidus $10^{4}$ & $98.9 \pm 0.5$ & $98.7 \pm 0.7$ & $99.3 \pm 0.4$ & $97.5 \pm 1.1$ & $95.4 \pm 1.0$ & & & & \\
\hline
\end{tabular}


Table 3. Survival $(\% \pm$ S.E.) and size ( $\mu \mathrm{m} \pm$ S.E.) of scallop larvae throughout the larval period. Larvae were cultured together until the sixth day (post-fertilization), after which they were separated into separate tanks and provided probiotics or antibiotics. Values within a column not sharing a superscript are statistically different $(\mathrm{p}<0.05)$. Columns without superscripts denote no statistical differences upon those days.

\begin{tabular}{|c|c|c|c|c|c|c|c|c|c|c|c|c|c|}
\hline Treatment & $\mathrm{d} 2$ & $\mathrm{~d} 4$ & d6 & d8 & d10 & d12 & d14 & $\mathrm{d} 16$ & d19 & d21 & d24 & d27 & d29 \\
\hline \multicolumn{14}{|l|}{ Survival } \\
\hline No probiotic (control) & 100 & 100 & $99.1 \pm 0.2$ & $99.1 \pm 0.3$ & $99.4 \pm 0.4^{b}$ & $97.1 \pm 0.7$ & $96.1 \pm 0.7^{\mathrm{abc}}$ & $92.8 \pm 1.3^{\mathrm{bc}}$ & $93.5 \pm 1.1^{\mathrm{abc}}$ & $89.2 \pm 2.3^{\mathrm{ab}}$ & $92.8 \pm 0.9$ & $91.3 \pm 0.7^{\mathrm{ab}}$ & $91.4 \pm 0.9$ \\
\hline Antibiotic & & & & $99.7 \pm 0.2$ & $97.3 \pm 0.7^{\mathrm{ab}}$ & $96.1 \pm 0.9$ & $91.2 \pm 1.6^{\mathrm{b}}$ & $87.8 \pm 1.3^{c}$ & $88.1 \pm 1.3^{\mathrm{c}}$ & $87.9 \pm 1.7^{b}$ & $88.3 \pm 1.1$ & $85.1 \pm 1.9^{b}$ & $85.0 \pm 2.6$ \\
\hline A. macleodii 0444 & & & & $99.2 \pm 0.4$ & $98.3 \pm 0.6^{\mathrm{ab}}$ & $96.3 \pm 1.1$ & $96.6 \pm 0.6^{\mathrm{ac}}$ & $94.3 \pm 1.0^{\mathrm{ab}}$ & $95.2 \pm 1.6^{\mathrm{ab}}$ & $93.3 \pm 0.8^{a b}$ & $93.7 \pm 0.5$ & $94.9 \pm 0.9^{\mathrm{a}}$ & $90.9 \pm 1.8$ \\
\hline Neptunomonas sp. 0536 & & & & $98.7 \pm 0.6$ & $97.4 \pm 0.7^{\text {ab }}$ & $98.6 \pm 0.5$ & $98.1 \pm 0.8^{\text {a }}$ & $96.8 \pm 0.8^{\mathrm{ab}}$ & $94.2 \pm 1.4^{\mathrm{abc}}$ & $94.9 \pm 1.2^{\mathrm{a}}$ & $92.4 \pm 2.7$ & $93.0 \pm 1.1^{\mathrm{ab}}$ & $92.8 \pm 1.3$ \\
\hline P. gallaeciensis & & & & $99.4 \pm 0.2$ & $96.6 \pm 0.8^{\mathrm{a}}$ & $95.3 \pm 0.9$ & $93.3 \pm 1.3^{\mathrm{bc}}$ & $92.7 \pm 1.1^{\mathrm{bc}}$ & $89.1 \pm 2.0^{\mathrm{bc}}$ & $92.7 \pm 1.1^{\mathrm{ab}}$ & $90.9 \pm 1.9$ & $89.0 \pm 2.0^{\mathrm{ab}}$ & $92.9 \pm 1.8$ \\
\hline Pseudoalteromonas sp. D41 & & & & $99.1 \pm 0.4$ & $98.1 \pm 0.6^{\mathrm{ab}}$ & $96.7 \pm 1.2$ & $95.9 \pm 0.7^{\mathrm{abc}}$ & $96.0 \pm 1.3^{\mathrm{ab}}$ & $94.9 \pm 1.1 \mathrm{ab}$ & $92.0 \pm 1.7^{\mathrm{ab}}$ & $92.7 \pm 1.6$ & $88.0 \pm 2.2^{\mathrm{ab}}$ & $84.0 \pm 3.3$ \\
\hline Probiotic mix & & & & $99.5 \pm 0.3$ & $98.4 \pm 0.5^{\mathrm{ab}}$ & $96.5 \pm 1.7$ & $97.9 \pm 0.8^{\mathrm{a}}$ & $97.7 \pm 0.7^{\mathrm{a}}$ & $97.2 \pm 0.8^{\mathrm{a}}$ & $95.2 \pm 1.1^{\mathrm{a}}$ & $93.7 \pm 1.3$ & $87.1 \pm 4.0^{\mathrm{ab}}$ & $91.0 \pm 1.1$ \\
\hline \multicolumn{14}{|l|}{ Shell size } \\
\hline$\overline{\text { No probiotic (control) }}$ & & & & & & & & $186.2 \pm 1.5^{\mathrm{a}}$ & & & $224.8 \pm 1.5^{\mathrm{a}}$ & $224.8 \pm 1.8^{\mathrm{a}}$ & $226.8 \pm 1.6^{\mathrm{ab}}$ \\
\hline Antibiotic & & & & & & & & $176.6 \pm 1.6^{\mathrm{b}}$ & & & $213.4 \pm 2.2^{\mathrm{bc}}$ & $218.2 \pm 2.1^{\mathrm{ab}}$ & $217.9 \pm 2.3^{\mathrm{cd}}$ \\
\hline A. macleodii 0444 & & & & & & & & $184.9 \pm 1.2^{\mathrm{ac}}$ & & & $215.7 \pm 2.0^{b}$ & $223.3 \pm 2.1^{\mathrm{a}}$ & $228.6 \pm 1.5^{\mathrm{a}}$ \\
\hline Neptunomonas sp. 0536 & & & & & & & & $183.5 \pm 1.2^{\mathrm{abc}}$ & & & $208.0 \pm 2.0^{\mathrm{bc}}$ & $214.4 \pm 2.1^{\mathrm{bc}}$ & $218.8 \pm 1.6^{\mathrm{cd}}$ \\
\hline P. gallaeciensis & & & & & & & & $180.0 \pm 1.4^{\mathrm{bc}}$ & & & $206.3 \pm 2.3^{c}$ & $224.1 \pm 1.9^{\mathrm{a}}$ & $220.4 \pm 1.8^{\mathrm{bc}}$ \\
\hline Pseudoalteromonas sp. D41 & & & & & & & & $182.3 \pm 1.3^{\mathrm{abc}}$ & & & $208.6 \pm 2.2^{b c}$ & $212.2 \pm 1.8^{\mathrm{c}}$ & $212.5 \pm 1.7^{\mathrm{d}}$ \\
\hline Probiotic mix & & & & & & & & $180.0 \pm 1.5^{\mathrm{bc}}$ & & & $215.3 \pm 1.9^{\mathrm{bc}}$ & $214.0 \pm 1.9^{\mathrm{bc}}$ & $214.2 \pm 1.6^{\text {cd }}$ \\
\hline
\end{tabular}


Figure 1. Yield of competent larvae ( $\% \pm$ S.E.), i.e. proportion of larvae to reach metamorphosis capability. Figures show: probiotic use alone (A) and probiotic use against pathogen-challenge (B). Columns not sharing a superscript are statistically different at day $29(\mathrm{p}<0.05)$.

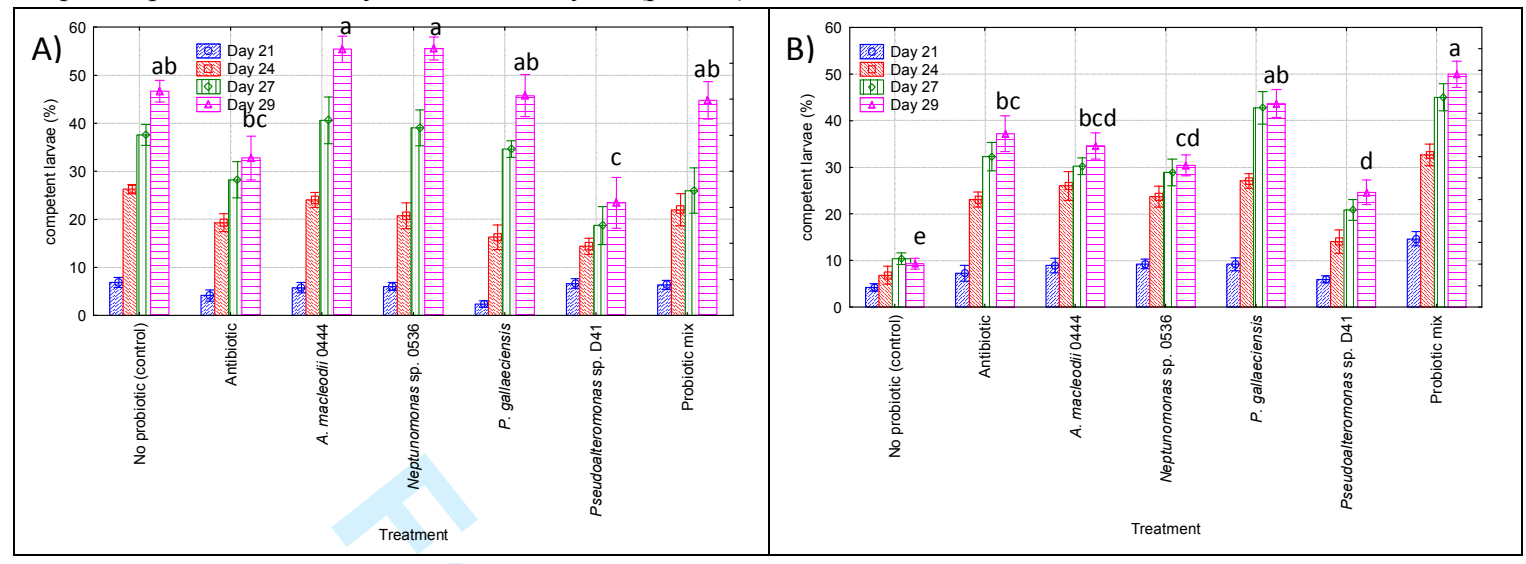


Table 4. Survival $(\% \pm$ S.E.) of scallop larvae throughout the larval period when challenged with pathogen, $V$. pectenicida, on the seventh day. Larvae were cultured together until the sixth day, after which they were separated into separate tanks and provided probiotics or antibiotics. Values within a column not sharing a superscript are statistically different $(\mathrm{p}<0.05)$.

\begin{tabular}{|c|c|c|c|c|c|c|c|c|c|c|c|c|c|}
\hline Treatment & $\mathrm{d} 2$ & $\mathrm{~d} 4$ & $\mathrm{~d} 6$ & d8 & $\mathrm{d} 10$ & d12 & d14 & d16 & d19 & $\mathrm{d} 21$ & d24 & d27 & d29 \\
\hline \multicolumn{14}{|l|}{ Survival } \\
\hline Pathogen control & 100 & 100 & $99.1 \pm 0.2$ & $99.2 \pm 0.5$ & $87.4 \pm 1.0^{\mathrm{b}}$ & $72.9 \pm 3.2^{\mathrm{c}}$ & $63.2 \pm 1.7^{\mathrm{c}}$ & $52.6 \pm 3.0^{\mathrm{d}}$ & $31.6 \pm 2.6^{\mathrm{d}}$ & $30.1 \pm 2.4^{\mathrm{c}}$ & $23.6 \pm 2.0^{\mathrm{d}}$ & $22.9 \pm 2.1^{\mathrm{d}}$ & $20.3 \pm 2.9^{\mathrm{c}}$ \\
\hline Antibiotic & & & & $99.2 \pm 0.3$ & $95.8 \pm 1.1^{\mathrm{a}}$ & $94.1 \pm 1.6^{\mathrm{a}}$ & $84.6 \pm 2.1^{\mathrm{a}}$ & $85.4 \pm 2.7^{\mathrm{a}}$ & $83.3 \pm 1.1^{\mathrm{a}}$ & $82.5 \pm 2.2^{\mathrm{a}}$ & $83.7 \pm 1.9^{\mathrm{a}}$ & $81.4 \pm 1.3^{\mathrm{a}}$ & $85.1 \pm 1.5^{\mathrm{a}}$ \\
\hline A. macleodii 0444 & & & & $98.9 \pm 0.3$ & $89.3 \pm 1.7^{b}$ & $79.9 \pm 2.4^{\mathrm{bc}}$ & $69.9 \pm 1.8^{\mathrm{c}}$ & $63.0 \pm 2.2^{\mathrm{cd}}$ & $52.8 \pm 3.4^{\mathrm{bc}}$ & $45.0 \pm 1.7^{\mathrm{b}}$ & $46.9 \pm 2.8^{\mathrm{bc}}$ & $45.8 \pm 0.8^{\mathrm{bc}}$ & $43.9 \pm 2.7^{\mathrm{b}}$ \\
\hline Neptunomonas sp. 0536 & & & & $99.1 \pm 0.4$ & $89.9 \pm 1.7^{b}$ & $81.1 \pm 2.2^{b c}$ & $72.2 \pm 2.3^{\mathrm{bc}}$ & $70.4 \pm 2.1 \mathrm{bc}$ & $63.9 \pm 1.7^{\mathrm{b}}$ & $55.1 \pm 3.7^{b}$ & $52.8 \pm 3.5^{\mathrm{b}}$ & $51.8 \pm 3.2^{b}$ & $49.6 \pm 2.9^{b}$ \\
\hline P. gallaeciensis & & & & $99.3 \pm 0.3$ & $85.1 \pm 1.7^{b}$ & $83.8 \pm 2.4^{\mathrm{bc}}$ & $79.6 \pm 2.8^{\mathrm{ab}}$ & $80.2 \pm 2.5^{\mathrm{ab}}$ & $79.9 \pm 3.0^{\mathrm{a}}$ & $76.3 \pm 3.6^{\mathrm{a}}$ & $78.3 \pm 1.8^{\mathrm{a}}$ & $81.4 \pm 1.6^{\mathrm{a}}$ & $79.6 \pm 2.5^{\mathrm{a}}$ \\
\hline Pseudoalteromonas sp. D41 & & & & $99.6 \pm 0.4$ & $82.8 \pm 2.4^{b}$ & $80.2 \pm 2.7^{b c}$ & $67.0 \pm 1.8^{c}$ & $58.1 \pm 2.7^{\mathrm{d}}$ & $47.5 \pm 1.9^{\mathrm{c}}$ & $46.4 \pm 2.1^{b}$ & $39.9 \pm 3.8^{c}$ & $38.5 \pm 2.6^{\mathrm{c}}$ & $43.5 \pm 2.6^{b}$ \\
\hline Probiotic mix & & & & $99.7 \pm 0.2$ & $89.9 \pm 1.0^{\mathrm{b}}$ & $85.8 \pm 1.9^{b}$ & $81.7 \pm 1.2^{\mathrm{a}}$ & $74.0 \pm 1.0^{\mathrm{b}}$ & $76.2 \pm 2.6^{\mathrm{a}}$ & $77.3 \pm 3.0^{\mathrm{a}}$ & $77.3 \pm 1.4^{\mathrm{a}}$ & $80.3 \pm 1.9^{\mathrm{a}}$ & $75.0 \pm 2.9^{\mathrm{a}}$ \\
\hline
\end{tabular}

